\title{
Electrochemical Determination of Ascorbigen in Sauerkrauts
}

\author{
Danuta Zielińska • Juana Frias • Elena Peñas • \\ Serafin Valverde • Henryk Zieliński • \\ Concepción Vidal-Valverde
}

Received: 30 March 2011 / Accepted: 14 June 2011 /Published online: 20 July 2011

(C) The Author(s) 2011. This article is published with open access at Springerlink.com

\begin{abstract}
Ascorbigen (ABG), 2-C-(indol-3-yl)methyl- $\alpha$-Lxylo-hex-3-ulofuranosono-1,4-lactone, was synthesised and its structure and purity was confirmed by means of ${ }^{1} \mathrm{H}$ NMR and ${ }^{13}$ C NMR spectra and HPLC-PDA, respectively. The electrochemical behaviour of ABG was studied by cyclic voltammetry (CV) method for $\mathrm{pH}$ within the range of 3.0-7.0 and further characterisation was performed by differential pulse voltammetry (DPV) at $\mathrm{pH}$ 5.0. Voltammetric studies of ABG at glassy carbon electrode showed one irreversible oxidation peak (centred at $E_{\mathrm{p}}=0.950 \mathrm{~V}$ for $\mathrm{pH}$ 5.0). The anodic peak current potential related to the irreversible oxidation of $\mathrm{ABG}$ was shifted towards more positive potentials with decreasing $\mathrm{pH}$ values. The linear response between concentration of $\mathrm{ABG}$ within the range of $0.08-0.75 \mathrm{mM}$ and recorded current was observed. The DPV method was shown to be more sensitive when
\end{abstract}

D. Zielińska $(\bowtie)$

Department of Chemistry,

University of Warmia and Mazury in Olsztyn,

Pl. Lodzki 4,

10-727 Olsztyn, Poland

e-mail: dziel@uwm.edu.pl

J. Frias $\cdot$ E. Peñas $\cdot$ C. Vidal-Valverde

Instituto de Ciencia y Tecnología

de Alimentos y Nutrición (CSIC),

Juan de la Cierva 3,

28006 Madrid, Spain

S. Valverde

Instituto de Quimica Organica (CSIC),

Juan de la Cierva 3 ,

28006 Madrid, Spain

\section{H. Zieliński}

Division of Food Science, Institute of Animal Reproduction and Food Research of the Polish Academy of Sciences,

Tuwima 10, P.O. Box 55, 10-747 Olsztyn, Poland compared to the $\mathrm{CV}$ method. ABG showed a significant reducing activity provided by $\mathrm{CV}$, whilst the antioxidant activity of ABG against $\mathrm{O}_{2}^{-\cdot}$ was negligible. Electrochemical behaviour of $A B G$ standard was applied successfully for the quantification of natural $\mathrm{ABG}$ in sauerkrauts by DPV and HPLC-CoulArray methods. Based on the developed analytical methods, ABG content increased during natural fermentation of cabbage at $0.5 \%$ and $1.5 \% \mathrm{NaCl}$ levels, and results were comparable with those found in the literature.

Keywords Ascorbigen · Cyclic voltammetry - Differential pulse voltammetry $\cdot$ HPLC-CoulArray $\cdot$ Antioxidant activity Sauerkraut

\section{Introduction}

Ascorbigen (ABG) is a natural breakdown product of glucosinolates (GLS) that is found in plants belonging to the Cruciferae family and naturally occurs in Brassica vegetables, mainly during fermentation of white cabbage (Wagner and Rimbach 2009). Epidemiological studies have shown that frequent Brassica vegetable consumption is associated with a reduced cancer risk (Zhang et al. 2006; Higdon et al. 2007; Śmiechowska et al. 2008). Their anticarcinogenic effect is probably due to their high amounts of GLS. When the plant tissue is damaged, GLS are broken down by the endogenous enzyme myrosinase ( $\beta$-thioglucoside glucohydrolase; EC 3.3.3.1) to release a complex variety of breakdown products (Mithen 2001).

GLS are sulphur-containing glucosides which are classified into aliphatic, aromatic and indole GLS depending on whether they originate from aliphatic amino acids, aromatic amino acids or tryptophan. During sauerkraut preparation, 
indole GLS glucobrassicin (GB) yields first an unstable isothiocyanate that further degrades with loss of $\mathrm{S}$ to form the intermediate indole-3-carbinol (I3C) that spontaneously reacts with $\mathrm{L}$-ascorbic acid forming $\mathrm{ABG}$ at acid $\mathrm{pH}$ (Zeligs 1998). It has been reported that ABG is not present in intact plant tissues (Preobrazhenskaya et al. 1993) or it is present in low quantities in just shredded cabbage because a certain amount of GB might have been hydrolysed by the endogenous myrosinase as a consequence of cell damage (Ciska and Pathak 2004; Martinez-Villaluenga et al. 2009; Peñas et al. 2010). ABG formation is strongly dependent on the $\mathrm{pH}$ and the already formed $\mathrm{ABG}$ remains relatively stable at $\mathrm{pH}$ 4-5 characteristics of fermented cabbage products (Aleksandrova et al. 1992). ABG is the most abundant indole GLS breakdown product in sauerkraut (Ciska and Pathak 2004; Agerbirk et al. 1998), a plant food product that has been widely consumed for centuries.

Several in vivo studies have revealed the anticarcinogenic properties of ABG (Sepkovic et al. 1994; Stephensen et al. 1999; Bonnesen et al. 2001). ABG is able to induce phase I and II enzymes that are centrally involved in the detoxification of xenobiotics (Wagner and Rimbach 2009; Higdon et al. 2007). Moreover, ABG is a moderate inducer of the phase II enzyme NQO1 (NADPH-quinone oxidoreductase) in both cultured hepatocytes and in vivo (Wagner et al. 2008a). In addition, ABG is thought to be an immunomodulating agent (Preobrazhenskaya et al. 1993) and its usefulness is largely attributed to its ability to support the body's natural metabolism of hormones (Michnovicz and Bradlow 1991). It is likely that some of the biological effects of $\mathrm{ABG}$ are mediated by its breakdown to ascorbic acid, a well-known antioxidant (Joshi et al. 2008).

ABG is a dietary supplement under the provisions of the US Dietary Supplement Health and Education Act of 1994 and it has now been recognised as a useful pharmacological substance with a variety of actions both in vitro and in vivo. The physical and chemical properties of ABG have been studied in detail and it has been reported to be relatively nontoxic (Joshi et al. 2008). However, The American Dietetic Association recommends that, whenever possible, people should consume the nutrients they need as foods and not as supplements (Hunt 1996) and, for instance, the consumption of fermented cabbage should be recommended.

During the last decade, normal-phase supercritical fluid chromatography (Buskov et al. 2000), thin-layer chromatography and overpressured layer chromatographic techniques (Kátay et al. 1997) and liquid chromatography/mass spectrometry (Wagner et al. 2008a) have been useful tools for $\mathrm{ABG}$ standard characterisation. In food matrices such as sauerkraut, however, one of the most useful methods used has been the high-performance liquid chromatography with UV detection HPLC-PAD (Martinez-Villaluenga et al. 2009; Peñas et al. 2010). Due to the importance of ABG bioactivity, the progress in analytical methods in food is still of scientific interest.

The electrochemical properties of ABG have not been investigated yet. The knowledge of these properties can be useful for further evaluation of the reducing activity of ABG. Due to its chemical structure, ABG can be subjected to complete oxidation-reduction studies. For this purpose, the cyclic voltammetry (CV) and differential pulse voltammetry (DPV) techniques and electrochemical detection, and specially the coulometric electrode array system, are particularly suitable for the $\mathrm{ABG}$ assay with special focus on its analyses in sauerkrauts. The coulometric electrode array detection system (HPLC-CoulArray) is a new method providing high precision, sensitivity and selectivity by independently setting different potentials in each cell of the detector (Zhang et al. 2008). The HPLC-coulometric array method also exhibits enhanced specificity due to the two-dimensional resolution achieved with retention time and the sequentially increasing potentials set at the coulometric electrodes in series (Yang et al. 2006).

Therefore, the following aims have been addressed in this study: (1) to characterise electrochemical behaviour of $\mathrm{ABG},(2)$ to determine the reducing power of $\mathrm{ABG}$ by $\mathrm{CV}$ method and then to compare it with the antioxidant activity of ABG determined against superoxide anion radical $\left(\mathrm{O}_{2}{ }^{-\cdot}\right)$ by a photochemiluminescence (PCL) assay and (3) to develop quantitative analytical methods for the determination of ABG in sauerkraut by DPV and HPLC with CoulArray detection.

\section{Materials and Methods}

\section{Chemicals and Reagents}

L-Ascorbic acid and 3-hydroxymethyl indole and 6-hydroxy2,5,7,8-tetramethylchroman-2-carboxylic acid (Trolox) were purchased from Sigma (Sigma Chemical Co., St. Louis, MO, USA). The PCL kit for the determination of the antioxidant activity of ABG was from Analytik Jena AG (Jena, Germany). Methanol, acetic acid (supra-gradient) and sodium acetate were from Merck KGaA, Darmstadt, Germany. All other reagents of reagent-grade quality were from $\mathrm{POCh}$, Gliwice, Poland. Water was purified with a Milli-Q system (Milipore, Bedford, USA).

Synthesis and Identification of Ascorbigen

ABG was obtained by the reaction of ascorbic acid and I3C, as shown in Fig. 1. The synthesis was carried out according 
Fig. 1 Synthesis of ABG

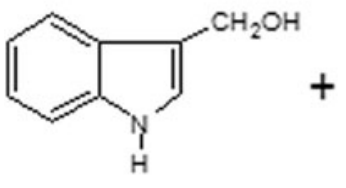

indole-3-carbinol (13C)<smiles>O=C1OC(C(O)CO)C(O)=C1O</smiles>

L-ascorbic acid (AA)

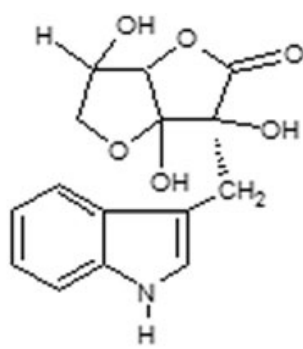

ascorbigen (ABG) to Kiss and Neukom (1966) with some modifications. Briefly, $440 \mathrm{mg}$ of ascorbic acid $(2.5 \mathrm{mM})$ was dissolved at room temperature in $20 \mathrm{ml}$ of McIlvaine buffer $\mathrm{pH} 4$ and $370 \mathrm{mg}$ of 3-hydroxymethyl indole $(2.5 \mathrm{mM})$ was added. The mixture was kept at room temperature for $1 \mathrm{~h}$, under nitrogen and protected from light. After filtration of solids, the solution was washed with ethyl ether and ethyl acetate. Evaporation of the ethyl acetate extract yielded pure ABG (200 mg), which was kept under nitrogen at $-20{ }^{\circ} \mathrm{C}$ and protected from light until further analysis. $A B G$ was identified by the ${ }^{1} \mathrm{H}$ NMR and ${ }^{13} \mathrm{C}$ NMR spectra. The ${ }^{1} \mathrm{H}$ NMR and ${ }^{13} \mathrm{C}$ NMR spectra of synthesised ABG were recorded on a Varian Inova Spectrometer operating at 400 and $50 \mathrm{MHz}$, respectively, using $\mathrm{CD}_{3} \mathrm{OD}$ as solvent. Purity of synthesised ABG was performed by HPLC using an Alliance Separation Module 2695 (Waters, Milford, USA) using an ODS-2 column $(150 \times 4.6 \mathrm{~mm}$ i.d.) (Waters) and a Photodiode Array Detector 996 at $280 \mathrm{~nm}$ (Waters, Milford, USA), as in Peñas et al. (2010).

\section{Plant Material and Sauerkraut Production}

The fresh white cabbages (Brassica oleracea L. ssp. capitata $\mathrm{cv}$. Bronco) used in this study were provided by Bejo Iberica S.L. (Madrid, Spain). Fresh cabbage heads were trimmed of outer leaves and their central core was removed. The edible part of the cabbages was then shredded into about 2-mm thick strips using a domestic shredder (Moka Express, Barcelona, Spain). Different salt concentrations $(0.5 \%$ or $1.5 \% \mathrm{NaCl})$ were added onto the shredded cabbage and mixed vigorously. Subsequently, cabbage and brine were transferred to autoclaved polyethylene (8 L; Nalge Nunc International, Rochester, NY, USA). The shredded cabbage was tightly pressed together to exclude air, so the subsequent lactic acid fermentation takes place. Fermentations were performed spontaneously by the autochthonous microbiota present on raw cabbage (natural fermentation). On the third day, cabbage was pricked to remove releasing fermentation gasses. Raw and fermented cabbages were freeze-dried, milled and stored at $-20{ }^{\circ} \mathrm{C}$ until their analysis.
Procedures

\section{Electrochemical Characterisation of Ascorbigen}

Stock solutions of $1 \mathrm{mM}$ ABG in $80 \%$ methanol were prepared. A series of $\mathrm{ABG}$ standards in $0.1 \mathrm{M}$ ammonium acetate buffer, $\mathrm{pH}$ 5.7, were prepared from the ABG stock solution and they were used for the investigation of the electrochemical properties of $\mathrm{ABG}$ by $\mathrm{CV}$ within the range of $0.05-1.0 \mathrm{mM}$ at $\mathrm{pH} 4-7$ and DPV within the range of $0.0125-0.1 \mathrm{mM}$ at $\mathrm{pH} 5$. The voltammetric experiments were performed with a potentiostat G750 (Gamry Instruments, Warminster, PA, USA). A conventional threeelectrode system consisting of a 3-mm diameter glassy carbon working electrode (BAS MF-2012), an $\mathrm{Ag} / \mathrm{AgCl}$ electrode as a reference electrode and platinum as counter electrode was used in the study.

\section{Determination of the Antioxidant Activity of Ascorbigen Against Superoxide Anion Radical}

The PCL method was used to measure the antioxidant activity of ABG against superoxide anion radicals $\left(\mathrm{O}_{2}{ }^{-\bullet}\right)$ generated from the photosensitiser luminol when it is exposed to UV light. The light source was a phosphoruscoated mercury discharge lamp with maximal excitation at $\lambda=351 \mathrm{~nm}$. The measurements were carried out with a Photochem ${ }^{\circledR}$ apparatus (Analytik Jena, Leipzig, Germany) according to Zielińska et al. (2007).

\section{Determination of Reducing Power of Ascorbigen by Cyclic} Voltammetry

Cyclic voltammetric experiments were performed with ABG standard solutions $(100 \mu \mathrm{M})$ or Trolox solutions $(0.1-2.5 \mathrm{mM})$ in $0.1 \mathrm{M}$ sodium acetate-acetic buffer (pH 5.0 in $80 \%$ methanol) according to Zielińska et al. (2008). The sodium acetate-acetic buffer acted also as a supporting electrolyte for the $\mathrm{CV}$ measurements. The cyclic voltammetric experiments were performed at room temperature using an electrochemical cell $(200 \mu \mathrm{l})$. The cyclic 
voltammograms were acquired in the range of -100 to $1,200 \mathrm{mV}$ at a scanning rate of $100 \mathrm{mV} \mathrm{s}^{-1}$. Prior to use, the surface of the glassy carbon electrode was carefully polished with $0.05 \mu \mathrm{m}$ alumina paste, ultrasonically rinsed in deionised water and then washed with methanol (Cosio et al. 2006). This procedure was repeated after each cycle. The total charge below the anodic wave curve of the ABG voltammogram was calculated. The cyclic voltammograms of Trolox solutions at a concentration range of $0.1-2.5 \mathrm{mM}$ was also acquired in the range of -100 to $1,200 \mathrm{mV}$, and then the reducing activity of ABG was expressed as Trolox equivalent antioxidant capacity.

\section{Determination of Antioxidant Activity and Reducing Power of Raw and Fermented Cabbages}

The PCL and CV methods were used as described for the ABG standard. Extracts from freeze-dried fresh and fermented cabbage were prepared as follows: $100 \mathrm{mg}$ of lyophilised sample was extracted with $1 \mathrm{ml}$ of $80 \%$ methanol and then extracted in triplicate by $30 \mathrm{~s}$ sonication. Next, the mixture was vortexed for $30 \mathrm{~s}$, again sonicated and vortexed and then centrifuged for $5 \mathrm{~min}\left(5,000 \times g\right.$ at $\left.4{ }^{\circ} \mathrm{C}\right)$ using a Beckman GS-15 R centrifuge (Beckman Instruments, Inc., Palo Alto, CA, USA). That step was repeated five times and supernatants were collected in 5-ml flask. Final extract concentration was $20 \mathrm{mg} / \mathrm{ml}$.

\section{DPV and HPLC-CoulArray Analysis of Ascorbigen in Fermented Cabbages}

Extraction of $\mathrm{ABG}$ from raw and fermented cabbage was carried out as described by Peñas et al. (2010). For the DPV

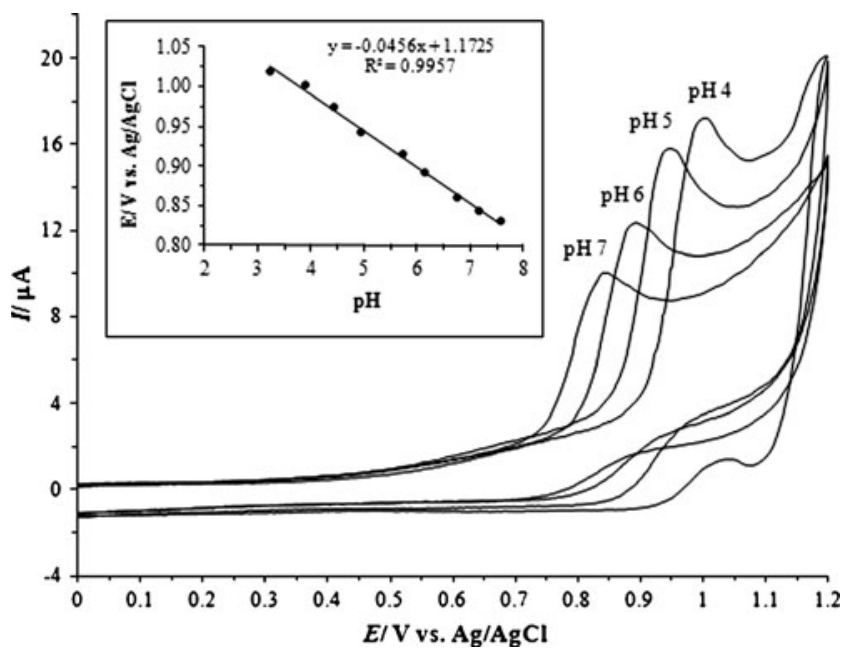

Fig. 2 Cyclic voltammograms of $0.25 \mathrm{mM} \mathrm{ABG}$ at $\mathrm{pH} 4.0,5.0,6.0$ and 7.0. Cyclic voltammograms were recorded from -100 to $+1,200 \mathrm{mV}$; scan rate, $100 \mathrm{mV} \mathrm{s}^{-1}$. Inset the dependence of the anodic peak current potential of $\mathrm{ABG}$ vs. $\mathrm{pH}$

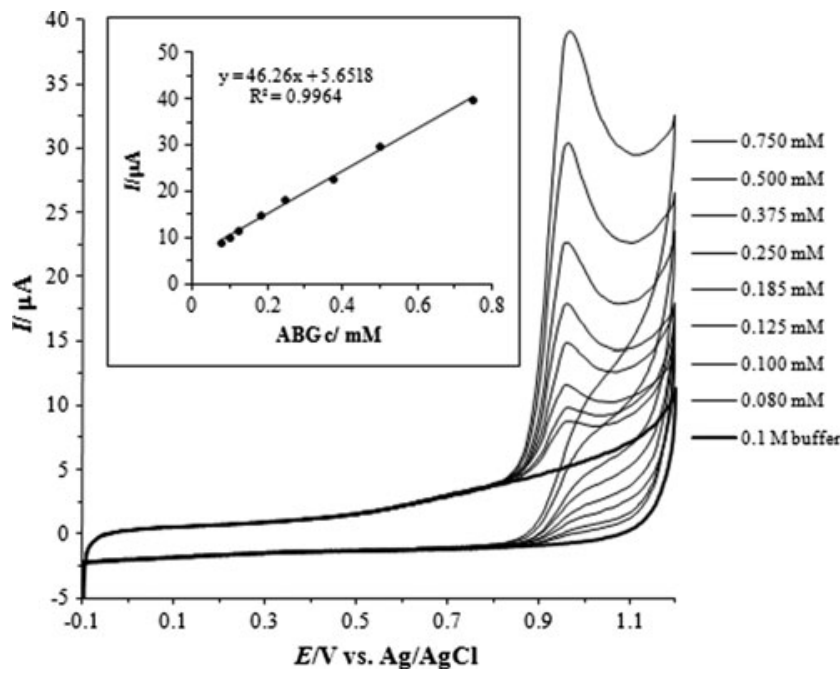

Fig. 3 Selected cyclic voltammograms of ABG within the concentration range of $0.08-0.75 \mathrm{mM}$ at $\mathrm{pH} 5.0$. Inset the linear response between the concentration of $\mathrm{ABG}$ and anodic peak current

measurements, the residue was dissolved in $80 \%$ methanol at a concentration of $200 \mathrm{mg} / \mathrm{ml}$ and differential pulse voltammograms were recorded at $\mathrm{pH}$ 5.0. The external standard addition method was applied for the identification and quantification of ABG. For the quantification of ABG by the HPLC-CoulArray detector, the residue was dissolved in mobile phase A composition (0.05 M ammonium acetate, $\mathrm{pH} 5.7$ containing $10 \%$ acetonitrile). Twenty microlitres of the sample was injected into a Hypersil Gold, $150 \times 4.6 \mathrm{~mm}$ i.d., $5 \mu \mathrm{m}$ size column (Thermo Scientific) at $30{ }^{\circ} \mathrm{C}$. The chro-

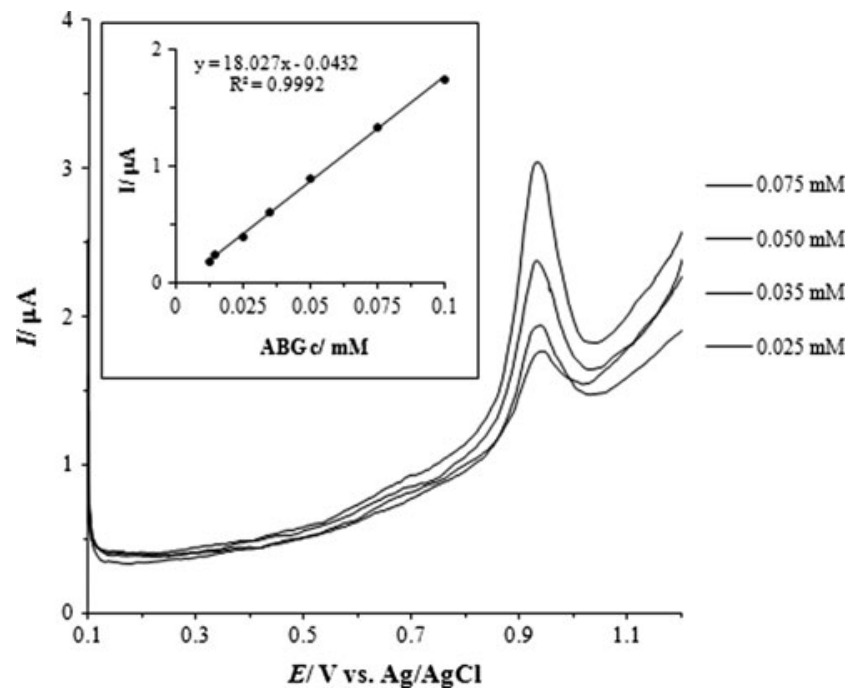

Fig. 4 Selected differential pulse voltammograms of different $A B G$ concentrations at $\mathrm{pH}$ 5.0. DPVs were recorded from 100 to $+1,200 \mathrm{mV}$; scan rate, $10 \mathrm{mV} \mathrm{s}^{-1}$. Inset the linear response between the concentration of $\mathrm{ABG}$ and anodic peak current 
Table 1 The antioxidant and reducing capacity of ABG standard, raw cabbage and sauerkrauts measured by PCL and CV methods

\begin{tabular}{lcc}
\hline Material & Antioxidant activity by PCL $(\mu \mathrm{mol}$ Trolox/g d.m.) & Reducing power by CV ( $\mu$ mol Trolox/g d.m.) \\
\hline ABG standard & $0.0128 \pm 0.0002 \mathrm{a}$ & $0.847 \pm 0.028 \mathrm{a}$ \\
Raw cabbage & $17.86 \pm 0.09 \mathrm{~b}$ & $14.36 \pm 0.62 \mathrm{~b}$ \\
$0.5 \% \mathrm{NaCl}$ sauerkraut & $22.28 \pm 0.71 \mathrm{~d}$ & $23.01 \pm 1.22 \mathrm{~d}$ \\
$1.5 \% \mathrm{NaCl}$ sauerkraut & $19.01 \pm 0.74 \mathrm{c}$ & $18.81 \pm 0.58 \mathrm{c}$ \\
\hline
\end{tabular}

Data are expressed as the means \pm standard deviations of three independent determinations. Means in a column followed by different lowercase letters correspond to significant differences $(P \leq 0.05)$

matogram was developed at a flow rate of $1.2 \mathrm{ml} / \mathrm{min}$ by eluting in a gradient of mobile phase A $(0.05 \mathrm{M}$ ammonium acetate, $\mathrm{pH} 5.7$ containing 10\% acetonitrile) and mobile phase $\mathrm{B}(0.05 \mathrm{M}$ ammonium acetate, $\mathrm{pH} 5.7$ containing $80 \%$ acetonitrile) as follows: isocratic $100 \%$ A for $1 \mathrm{~min}, 50 \% \mathrm{~A}-50 \% \mathrm{~B}$ linear gradient for $12 \mathrm{~min}$, isocratic $50 \% \mathrm{~A}-50 \% \mathrm{~B}$ for $3 \mathrm{~min}$, linear gradient $0 \%$ A-100\% B for $5 \mathrm{~min}$ and isocratic $100 \% \mathrm{~A}-0 \% \mathrm{~B}$ for $5 \mathrm{~min}$ (to equilibrate to initial conditions). Detection was carried out at $810 \mathrm{mV}$. The ABG standard was used for identification and quantification by HPLC. The calibration curve was plotted and adjusted by using the method of least squares. The regression coefficient of the ABG curve was $>0.990$.

\section{Statistical Analysis}

Data were subjected to one-way analysis of variation (ANOVA) using Duncan's multiple range test for uniform group. The significant differences $(P \leq 0.05)$ were calculated. The statistical analysis was carried out with a Statistica ver. 5.0 software (General Convention and Statistics 1995).

\section{Results and Discussion}

\section{Characterisation of Ascorbigen}

The ABG synthesised was analysed by ${ }^{1} \mathrm{H}$ NMR and ${ }^{13} \mathrm{C}$ NMR. Chemical shifts were expressed as parts per million (ppm) and were referenced to the residual protons of the solvent. The following shifts were obtained: ${ }^{1} \mathrm{H}$ NMR (300 MHz, CD $\mathrm{CD}_{3} \mathrm{OD}(\mathrm{ppm}): 3.41(\mathrm{~d}, 1 \mathrm{H}), 3.61(\mathrm{~d}, 1 \mathrm{H})$, $3.98(\mathrm{~s}, 1 \mathrm{H}), 4.18(\mathrm{dd}, 1 \mathrm{H}), 4.31(\mathrm{dd}, 1 \mathrm{H}), 4.40(\mathrm{dd}, 1 \mathrm{H}), 7.17$ $(\mathrm{t}, 1 \mathrm{H}), 7.23(\mathrm{t}, 1 \mathrm{H}), 7.40(\mathrm{~s}, 1 \mathrm{H}), 7.51(\mathrm{~d}, 1 \mathrm{H}), 7.81(\mathrm{~d}, 1 \mathrm{H}) ;{ }^{13}$ C NMR (50 MHz, CD $\left.\mathrm{CD}_{3} \mathrm{OD}\right) \delta$ (ppm): 178.72, 137.52, $129.09,126.58,122.24,119.99,119.73,112.04,108.68$, 107.50, 88.29, 80.90, 75.51, 75.49, 31.80. The ${ }^{1} \mathrm{H}$ NMR and ${ }^{13} \mathrm{C}$ NMR spectra of ABG were identical to values reported previously (Preobrazhenskaya et al. 1996). Synthesised ABG was quantified by the HPLC-PAD devise at $280 \mathrm{~nm}$ and the purity was superior to $99.5 \%$.
Electrochemical Characterisation of Ascorbigen

The reducing activity of $\mathrm{ABG}$ was studied by $\mathrm{CV}$ at $\mathrm{pH}$ within the range of 3.0-7.0 (Fig. 2). The peak current potential related to the irreversible oxidation of $A B G$ was
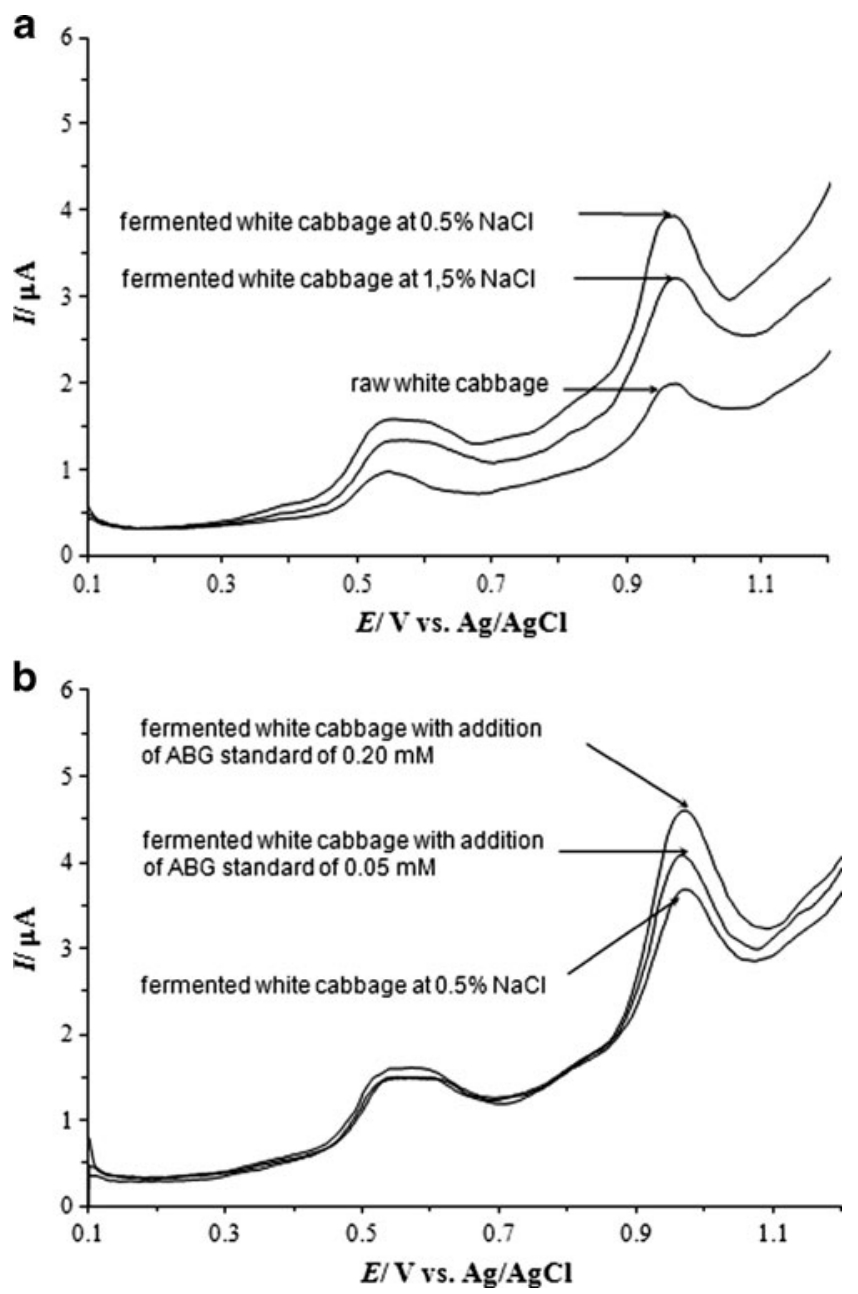

Fig. 5 a The DPVs of extracts of raw (lower line) and naturally fermented white cabbage at $0.5 \%$ (upper line) and $1.5 \%$ salt level (middle line); $\mathbf{b}$ DPVs of the extract of fermented white cabbage at $0.5 \% \mathrm{NaCl}$ (lower spectra) with the addition of $\mathrm{ABG}$ standard at a final concentration of $0.05,0.1$ and $0.2 \mathrm{mM}$ in an extract 
Table 2 Content of $\mathrm{ABG}$ in raw cabbage (B. oleracea $\mathrm{L}$. var. capitata cv. Bronco) and $0.5 \%$ and $1.5 \% \mathrm{NaCl}$ sauerkrauts

\begin{tabular}{llr}
\hline Material & DPV & HPLC-CoulArray \\
\hline Raw cabbage & $20.5 \pm 1.0 \mathrm{a}$ & $21.6 \pm 1.4 \mathrm{a}$ \\
$0.5 \% \mathrm{NaCl}$ sauerkraut & $88.1 \pm 2.8 \mathrm{c}$ & $107.3 \pm 1.0 \mathrm{c}$ \\
$1.5 \% \mathrm{NaCl}$ sauerkraut & $68.4 \pm 1.2 \mathrm{~b}$ & $77.4 \pm 1.1 \mathrm{~b}$ \\
\hline
\end{tabular}

Data are expressed in micromoles per $100 \mathrm{~g} \mathrm{d.m}$. and are the means \pm standard deviations of three independent determinations. Means within a column followed by different lowercase letters correspond to significant differences $(P \leq 0.05)$
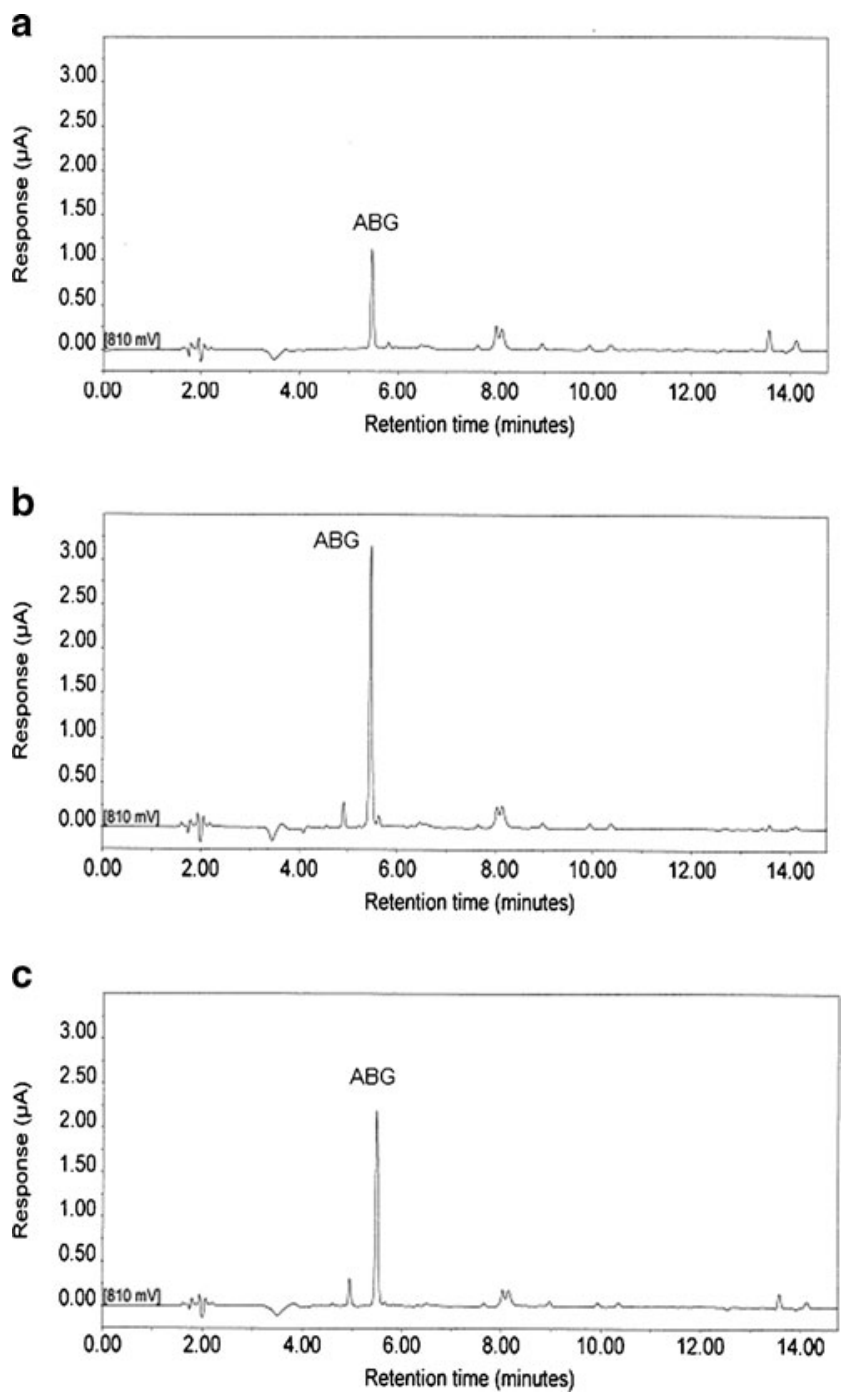

Fig. 6 HPLC-CoulArray chromatograms (applied potential, $810 \mathrm{mV}$ ) of extract from a raw and naturally fermented white cabbage at $\mathbf{b}$ $0.5 \% \mathrm{NaCl}$ and $\mathbf{c} 1.5 \% \mathrm{NaCl}$ levels. The sample $(20 \mu \mathrm{l})$ was injected into a Hypersil Gold column $(150 \times 4.6 \mathrm{~mm}, 5 \mu \mathrm{m}$, Thermo Scientific $)$ at $30{ }^{\circ} \mathrm{C}$. The chromatogram was developed at a flow rate of $1.2 \mathrm{ml} /$ min in a gradient of mobile phase A $(10 \%$ acetonitrile, $0.05 \mathrm{M}$ ammonium acetate, $\mathrm{pH} 5.7)$ and mobile phase $\mathrm{B}(80 \%$ acetonitrile, $0.05 \mathrm{M}$ ammonium acetate, $\mathrm{pH}$ 5.7) as follows: $100-100-50-50-0$ $100 \% \mathrm{~B}$ at gradient time of $0-1-13-16-21-26 \mathrm{~min}$ shifted towards more positive potentials with decreasing $\mathrm{pH}$ values. At $\mathrm{pH} 4-5.0$, which is the $\mathrm{pH}$ typical for sauerkrauts, CV studies of ABG at glassy carbon electrode showed oxidation peak centred at $E_{\mathrm{p}}=0.950 \mathrm{~V}$ and linear response at $0.25 \mathrm{mM}$ was found between $\mathrm{pH}$ and anodic peak current potential. Oxidation peak for ascorbic acid by $\mathrm{CV}$ was also recorded and occurred at $E_{\mathrm{p}}=0.376 \mathrm{~V}$ (cyclic voltammogram not shown), excluding any interference between both compounds. The linear response between concentrations of ABG within the range of $0.08-0.75 \mathrm{mM}$ and anodic peak current at selected $\mathrm{pH} 5.0$ was observed (Fig. 3). The DPV offers higher sensitivity when compared to $\mathrm{CV}$ method. In this experiment, the linear response of the anodic peak current vs. ABG concentration in a lower range of $0.0125-0.10 \mathrm{mM}$ was provided (Fig. 4) and the oxidation peak related to $\mathrm{ABG}$ at $\mathrm{pH} 5.0$ was noted at $E_{\mathrm{p}}=0.950 \mathrm{~V}$.

Antioxidant Activity and Reducing Power of Ascorbigen, Raw and Fermented Cabbages

Table 1 collects the antioxidant activity and reducing power of ABG standard measured by PLC and CV methods. The antioxidant activity of ABG against superoxide anion radicals $\left(\mathrm{O}_{2}^{-{ }^{-}}\right)$evaluated by PCL was very low $(0.0128 \pm$ $0.0002 \mathrm{mM}$ of Trolox), whilst the reducing power of $\mathrm{ABG}$ provided by $\mathrm{CV}$ experiments was rather higher $(0.847 \pm$ $0.028 \mathrm{mM}$ of Trolox). Different antioxidant activity of ABG has been found in the literature. Wagner et al. (2008b) indicated that $\mathrm{ABG}$ did not scavenge superoxide anion free radicals and showed only little scavenging activity toward 2,2-diphenyl-1-picrylhydrazyl free radicals (DPPH radicals). Similarly, a weaker antioxidant activity of ABG in comparison with ascorbic acid was measured against radicals produced by decomposition of 2,2'-diazobis(2-amidinopropane) dihydrochloride (AAPH) has been reported (Joshi et al. 2008). Therefore, antioxidative effects of ABG may also be

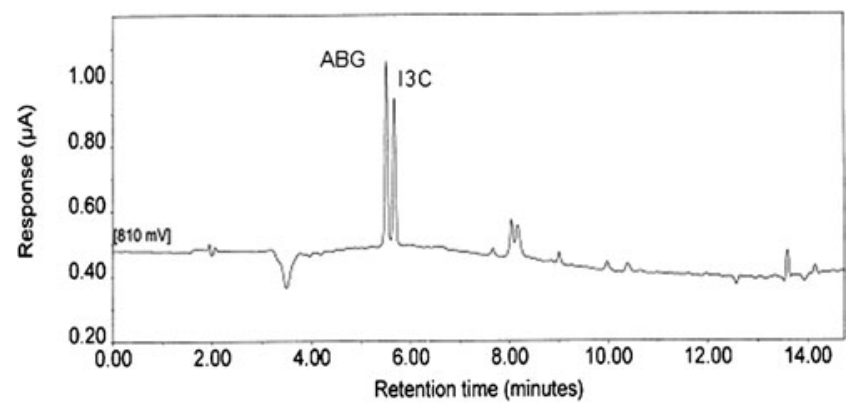

Fig. 7 HPLC-CoulArray chromatogram (applied potential, $810 \mathrm{mV}$ ) of the mixture $\mathrm{I} 3 \mathrm{C}$ and $\mathrm{ABG}$ standard solution at final concentrations of 0.8 and $1.7 \mu \mathrm{M}$, respectively. The chromatogram was developed as described in Fig. 6 
mediated by other mechanisms than its free radical scavenging per se, as it has been suggested by Wagner et al. (2008b). Furthermore, most of the GLS hydrolysis products do not neutralise free radicals directly but they exert an indirect antioxidant activity, which enhance the activity of xenobiotic-metabolizing enzymes triggering the long-lasting antioxidant activity (Vig et al. 2009).

Antioxidant activity and reducing power of raw and fermented cabbage were evaluated by PCL and CV methods (Table 1) and they were rather larger than those observed for the ABG standard. Among them, $0.5 \% \mathrm{NaCl}$ sauerkraut showed statistically $(P \leq 0.05)$ higher antioxidant capacity, followed by the $1.5 \% \mathrm{NaCl}$ and the raw cabbage. These results indicate that other different compounds present in sauerkrauts than $\mathrm{ABG}$ are contributing to the antioxidative and reducing capacities of raw and fermented cabbages measured by PCL and CV methods, respectively.

Application of DPV and HPLC-CoulArray

for the Determination of Ascorbigen in Raw

and Fermented Cabbages

Since $\mathrm{ABG}$ is an electroactive compound, the use of an electrochemical method for its quantitative analyses is feasible. Firstly, differential pulse voltammograms of sauerkraut extracts were recorded at $\mathrm{pH} 5$, which is typical of sauerkraut products. The anodic peak current corresponding to $A B G$ in extracts originated from sauerkrauts was higher than that one related to $A B G$ from raw cabbage extracts (Fig. 5a). The presence of ABG in fermented cabbages was confirmed by the addition of external ABG standard. For this purpose, final concentrations of 0.05 and $0.1 \mathrm{mM} \mathrm{ABG}$ standard were added, and the recorded DPVs clearly confirmed the dose-dependent ratio between anodic peak current and ABG concentration (Fig. 5b). Based on the linear response of the anodic peak current vs. ABG standard concentration within a range of $10-100 \mu \mathrm{M}$ provided by the DPV method (Fig. 4), the content of ABG in raw cabbage and sauerkrauts was calculated (Table 2). The content of $\mathrm{ABG}$ in raw and fermented cabbage at $0.5 \%$ and $1.5 \% \mathrm{NaCl}$ was rather similar than what has been previously provided by HPLC-PAD quantification by Peñas et al. (2010) $(14,100$ and $75 \mu \mathrm{mol} / 100 \mathrm{~g}$ d.m., respectively), and differences among methods ranged between $9 \%$ and $15 \%$. The results show that DPV represents a simple, fast and low-cost analytical method for screening the ABG content in fermented cabbage products.

To take the most of the electrochemical properties of ABG, the analysis of raw and fermented cabbage was also carried out by the HPLC-CoulArray detector. The analyses were carried out at $\mathrm{pH}$ 5.7, as in the case of HPLC-PAD analysis (Peñas et al. 2010). At this $\mathrm{pH}$, the highest sensitivity of the CoulArray detector was achieved at $E_{\mathrm{p}}=810 \mathrm{mV}$ and chromatograms of raw and fermented cabbage at $0.5 \%$ and $1.5 \% \mathrm{NaCl}$ are shown in Fig. 6. ABG content in raw cabbage and sauerkrauts was obtained in base on the $\mathrm{ABG}$ standard curve in a range of $0.82-3.28 \mu \mathrm{M}$ (correlation coefficients $R^{2}=0.9975$ ) and the results are presented in Table 2. The detection limit was $15 \mathrm{ng} / \mathrm{L}$, with the signal to noise ratio of $3: 1$. In general, $A B G$ content in raw cabbage was low ( 21 to $22 \mu \mathrm{mol} / 100 \mathrm{~g}$ d.m.) and natural fermentation led to a sharp increment on $\mathrm{ABG}$ content to values of 107 and $77 \mu \mathrm{mol} / 100 \mathrm{~g} \mathrm{~d} . \mathrm{m}$. for $0.5 \%$ and $1.5 \%$ $\mathrm{NaCl}$ sauerkrauts, respectively. These results are comparable to those previously obtained by HPLC-PDA (100 and $75 \mu \mathrm{mol} / 100 \mathrm{~g}$ d.m., respectively) (Peñas et al. 2010) and DPV methods (Table 2), and only a $3-15 \%$ deviation range between methods was shown. Moreover, analysis of sauerkraut by HPLC-CoulArray showed the absence of I3C; however, this method in one run allows to separate $\mathrm{I} 3 \mathrm{C}$ and ABG from solution containing both compounds (Fig. 7). The separation was achieved due to the differences in the retention time, which was $5.551 \mathrm{~min}$ for $\mathrm{ABG}$ and $5.67 \mathrm{~min}$ for I3C. It can be concluded that both electrochemical methods are fully applicable for the screening of $\mathrm{ABG}$ amounts in sauerkrauts.

\section{Conclusion}

In this study, the spectral behaviour of ABG was applied to develop quantitative analytical methods for the determination of ABG in sauerkraut by DPV and HPLC with CoulArray detection. It was shown that the $\mathrm{ABG}$ standard was an electroactive compound, based on its electrochemical behaviour studied by $\mathrm{CV}$ and DPV on the GC electrode. ABG showed a significant reducing power provided by $\mathrm{CV}$, whilst its antioxidant activity against $\mathrm{O}_{2}{ }^{-}$was negligible. Despite of the common reversed-phase HPLC with UV detection method used for ABG quantification, both electrochemical DPV and HPLC-CoulArray methods have been successfully used for the direct determination of ABG in sauerkrauts.

Acknowledgements This work was supported in part by the Spanish Commission of Science and Technology AGL2007-62044 and by grant no. 5056/B/P01/2011/40 from the Polish Ministry of Science and Higher Education.

Open Access This article is distributed under the terms of the Creative Commons Attribution Noncommercial License which permits any noncommercial use, distribution, and reproduction in any medium, provided the original author(s) and source are credited.

\section{References}

Agerbirk N, Olsen CE, Sørensen H (1998) J Agric Food Chem 46:1563 
Aleksandrova LG, Korolev AM, Probrazhenskaya M (1992) Food Chem 45:61

Bonnesen C, Eggleston IM, Hayes JD (2001) Cancer Res 61:6120

Buskov S, Hansen LB, Olsen CE, Sørensen FC, Sørensen H, Sørensen S (2000) J Agric Food Chem 48:2693

Ciska E, Pathak DR (2004) J Agric Food Chem 52:7938

Cosio MS, Buratti S, Mannino S, Benedetti S (2006) Food Chem 97:725

Higdon JV, Delage B, Williams DE, Dashwood RH (2007) Pharmacol Res 55:224

Hunt J (1996) J Am Diet Assoc 96:73

Joshi MS, Bauer JA, Werbovetz KA, Barszcz T, Patil PN (2008) Phytother Res 22:1581

Kátay Gy, Mincsovics E, Szókán Gy, Tyihák E (1997) J Chromatogr A 764:103

Kiss G, Neukom H (1966) Helv Chim Acta 49:989

Martinez-Villaluenga C, Peñas E, Frias J, Ciska E, Honke J, Piskula MK, Kozlowska H, Vidal-Valverde C (2009) J Food Sci 74(1):C62

Michnovicz JJ, Bradlow HL (1991) Nutr Cancer 16:59

Mithen RF (2001) Adv Botan Res 35:214

Peñas E, Frias J, Sidro B, Vidal-Valverde C (2010) J Agric Food Chem 58:3549

Preobrazhenskaya MN, Bukhman VM, Korolev AM, Efimov SA (1993) Pharmac Ther 60:301

Preobrazhenskaya MN, Lazhko EI, Korolev AM (1996) Tetrahd Asymm 7:641
Sepkovic DW, Bradlow HL, Michnovicz J, Murtezani S, Levi I, Osborne MP (1994) Steroids 59:318

Śmiechowska A, Bartoszek A, Namieśnik J (2008) Postepy Hig Med Dosw 62:125

General Convention and Statistics (1995) In: Statistica for Windows, vol. I-III, 2nd edn. StatsoftInc., Tulsa

Stephensen PU, Bonnesen C, Bjeldanes LF, Vang O (1999) Biochem Pharmacol 58:1145

Vig AP, Rampal G, Thind TS, Arora S (2009) LWT Food Sci Technol 42:1561

Wagner AE, Rimbach G (2009) Clin Dermatol 27:217

Wagner AE, Hug H, Gossl R, Riss G, Mussler B, Elste V, Rimbach G, Barella L (2008a) Ann Nutr Metab 53:122

Wagner AE, Huebbe P, Konishi T, Rahman MM, Nakahara M, Matsugo S, Rimbach G (2008b) Food Chem 56:11694

Yang Z, Zhang X, Guo H, Gan Y (2006) Anal Lett 39:1837

Zeligs MA (1998) J Med Food 1(2):67

Zhang Y, Munday REX, Jobson HE, Munday CM, Lister C, Wilson P, Fahey JW, Mhawech-Fauceglia P (2006) J Agric Food Chem 54:9370

Zhang X, Ma L, Zhang H, Gan Y (2008) Anal Lett 41:1047

Zielińska D, Szawara-Nowak D, Ornatowska A, Wiczkowski W (2007) J Agric Food Chem 55:9891

Zielińska D, Wiczkowski W, Piskuła MK (2008) J Agric Food Chem $56: 3524$ 